\title{
Monitoring Compliance and Examining Challenges of a Smoke-free Policy in Jayapura, Indonesia
}

\author{
Wahyuti Wahyuti ${ }^{1,2}$, Suci K. Hasairin ${ }^{3}$, Sherly N. Mamoribo ${ }^{2}$, Abdillah Ahsan ${ }^{4}$, Dian Kusuma ${ }^{5}$ \\ ${ }^{1}$ Postgraduate Program in Sociology, State University of Makassar, Makassar, Indonesia; ${ }^{2}$ Department of Health Promotion, Faculty of Public \\ Health, Cenderawasih University, Jayapura, Indonesia; ${ }^{3}$ Department of Epidemiology, Faculty of Public Health, Hasanuddin University, Makassar, \\ Indonesia; ${ }^{4}$ Faculty of Economics and Business, University of Indonesia, Depok, Indonesia; ${ }^{5}$ Centre for Health Economics and Policy Innovation, \\ Imperial College Business School, London, United Kingdom
}

Objectives: In Indonesia, 61 million adults smoked in 2018, and 59 million were exposed to secondhand smoke at offices or restaurants in 2011. The Presidential Decree 109/2012 encouraged local governments to implement a smoke-free policy (SFP), and the city of Jayapura enacted a local bill (1/2015) to that effect in 2015. This study aimed to evaluate compliance with this bill and to explore challenges in implementing it.

Methods: We conducted a mixed-methods study. Quantitatively, we assessed compliance of facilities with 6 criteria (per the bill): the presence of signage, the lack of smoking activity, the lack of sale of tobacco, the lack of tobacco advertisements, the lack of cigarette smoke, and the lack of ashtrays. We surveyed 192 facilities, including health facilities, educational facilities, places of worship, government offices, and indoor and outdoor public facilities. Qualitatively, we explored challenges in implementation by interviewing 19 informants (government officers, students, and community members).

Results: The rate of compliance with all 6 criteria was $17 \%$ overall, ranging from $0 \%$ at outdoor public facilities to $50 \%$ at health facilities. Spatial patterning was absent, as shown by similar compliance rates for SFP facilities within a 1-km boundary around the provincial and city health offices compared to those outside the boundary. Implementation challenges included (1) a limited budget for enforcement, (2) a lack of support from local non-governmental organizations and universities, (3) a lack of public awareness at the facilities themselves, and (4) a lack of examples set by local leaders.

Conclusions: Overall compliance was low in Jayapura due to many challenges. This information provides lessons regarding tobacco control policy in underdeveloped areas far from the central government.

Key words: Compliance, Smoke-free policy, Tobacco control, Jayapura, Indonesia

\section{INTRODUCTION}

Received: August 27, 2019 Accepted: October 25, 2019

Corresponding author: Dian Kusuma, ScD

Centre for Health Economics and Policy Innovation, Imperial College

London, South Kensington Campus, London SW7 2AZ, United Kingdom

E-mail: d.kusuma@imperial.ac.uk

This is an Open Access article distributed under the terms of the Creative Commons Attribution Non-Commercial License (http://creativecommons.org/licenses/bync/4.0/) which permits unrestricted non-commercial use, distribution, and reproduction in any medium, provided the original work is properly cited.
Indonesia has over 60 million current smokers and has the second highest smoking prevalence among adult men in the world [1]. The latest national health survey showed that the smoking prevalence among adults had stagnated recently but remained high, while that among youth (10-18 years old) increased from 2013 to 2018 [2]. Additionally, data from the Global Adult Tobacco Survey showed that 59 million adults were exposed to secondhand smoke at offices or restaurants 
in 2011 [3]. Despite this, Indonesia is 1 of only 9 countries whose government has not ratified the World Health Organization's Framework Convention on Tobacco Control.

Indonesia has passed 2 national regulations related to tobacco control: the Health Act 36/2009 and the Presidential Decree 109/2012. The Health Act issued general guidance regarding health warnings on cigarette packs and recommended that local governments implement a smoke-free policy (SFP) [4]. The Presidential Decree provided further information prohibiting the production, sale, advertisement, promotion, and smoking of tobacco products in SFP facilities, including health and educational facilities [5]. However, evidence has shown that only 345 of 514 districts (67\%) have adopted some form of SFP regulation as of December 2018, a decade after the Health Act's passage [6]. This is partly because, since decentralization, the adoption of national policies has relied on district governments. Moreover, compliance levels vary greatly in the districts subject to some form of SFP, from $20 \%$ in Jakarta [7] to $78 \%$ in the city of Bogor [8].

An SFP was adopted in Jayapura through a local bill (1/2015), which was supported by the mayor and the local parliament. The bill banned the sale, advertisement, promotion, and smoking of tobacco products in various facilities, including health facilities, educational facilities, places of worship, offices, and indoor and outdoor public facilities. However, the bill has been criticized, including by government officials, on the basis of the lack of enforcement of and poor compliance with the bill, even after 2 years [9]. This study aimed to evaluate compliance with the SFP and to explore the challenges in implementing it in Jayapura, in order to make a novel contribution to the literature. The findings are important for global health, as they provide details of tobacco control policy implementation [10] in areas that are relatively undeveloped and far from the central government.

The city of Jayapura is the capital of the province of Papua, with a population of over 290000 in 2017 [11]. Apart from the SFP in 2015, more comprehensive local tobacco control measures, such as bans on outdoor advertising of tobacco and on tobacco product displays, are lacking.

\section{METHODS}

This is a mixed-methods study, as it employed both quantitative and qualitative methods. Quantitatively, the study assessed compliance with 6 SFP criteria: the presence of signage, lack of smoking activity, lack of sale of tobacco, lack of tobacco advertisements, lack of cigarette smoke, and lack of ashtrays (per the bill 1/2015). The facilities assessed included health facilities (e.g., hospitals and government clinics), educational facilities (e.g., educational institutions from kindergartens to universities), indoor public facilities (e.g., public transport vehicles, malls, hotels, cafés, restaurants, and child play stations), and outdoor public facilities (e.g., bus terminals, traditional markets, recreational and sport facilities, and parks). Due to limited resources, we used purposive sampling of 192 facilities in 5 subdistricts, including 10 health facilities, 69 educational facilities, 30 places of worship, 13 government offices, 51 indoor public facilities, and 19 outdoor public facilities (Table 1). Qualitatively, we explored challenges in the implementation of the SFP by conducting in-depth interviews with 19 informants, including 11 government officers from the city offices (e.g., health, education, transportation, labor, tourism, women and child empowerment, and civil police offices) and 8 university students and members of the community living near the facilities. Each interview was recorded and lasted up to 90 minutes, and all interviews were conducted at government offices or houses near SFP facilities. Data collection was performed by 6 trained enumerators and interviewers between October and December 2018.

We conducted 3 types of data analysis: descriptive analysis, spatial analysis, and content analysis. Descriptive analysis was conducted using Stata version 15.1 (StataCorp., College Station, TX, USA) to show the compliance rates across all facilities (overall), within facility groups (e.g., health facilities or educational facilities), and within each facility type (e.g., primary schools or hospitals). Spatial analysis was conducted using ArcMap 10.6 (Esri, Redlands, CA, USA) to explore any spatial patterns in SFP compliance. We used ArcMap's geoprocessing buffer tool to generate a 1-km buffer region (constituting about a 15-minute walk) around each of 4 facilities (the governor's office, the mayor's office, the provincial health office, and the district health office), which served as proxies for the main supporters of the SFP. We then compared the compliance rates of facilities inside the buffer with those outside the buffer (Figure 1). The geolocations of the facilities were collected using Google MyMaps (Google Inc., Mountain View, CA, USA) after the survey was conducted. Thematic content analysis was used to identify the main themes of the challenges in implementing the SFP. 
Table 1. Rates (\%) of compliance with the smoke-free policy by facility type in Jayapura, 2018

\begin{tabular}{|c|c|c|c|c|c|c|c|c|}
\hline Characteristics & $\mathbf{N}$ & Signage & No smoking & No sale & No advertisement & No smoke & No ashtrays & Compliance with all 6 \\
\hline Overall & 192 & 28 & 66 & 91 & 95 & 72 & 92 & 17 \\
\hline \multicolumn{9}{|l|}{ Facility type } \\
\hline Health facility ${ }^{1}$ & 10 & 80 & 80 & 100 & 100 & 70 & 100 & 50 \\
\hline Educational facility ${ }^{1}$ & 69 & 36 & 84 & 99 & 99 & 90 & 96 & 29 \\
\hline Place of worship ${ }^{2}$ & 30 & 7 & 57 & 100 & 97 & 73 & 100 & 3 \\
\hline Government workplace & 13 & 62 & 23 & 92 & 100 & 23 & 100 & 15 \\
\hline Public facility (indoor) & 51 & 18 & 67 & 88 & 96 & 76 & 76 & 8 \\
\hline Public facility (outdoor) & 19 & 11 & 32 & 47 & 74 & 32 & 100 & 0 \\
\hline \multicolumn{9}{|l|}{ Facility } \\
\hline \multicolumn{9}{|l|}{ Health } \\
\hline Hospital & 6 & 67 & 67 & 100 & 100 & 67 & 100 & 33 \\
\hline Government clinic & 4 & 100 & 100 & 100 & 100 & 75 & 100 & 75 \\
\hline \multicolumn{9}{|l|}{ Education } \\
\hline Kindergarten & 12 & 17 & 92 & 100 & 92 & 100 & 100 & 17 \\
\hline Primary school & 19 & 42 & 89 & 100 & 100 & 95 & 95 & 37 \\
\hline Junior high school & 16 & 44 & 94 & 100 & 100 & 100 & 100 & 38 \\
\hline Senior high school & 14 & 36 & 79 & 100 & 100 & 86 & 93 & 21 \\
\hline University & 8 & 38 & 50 & 88 & 100 & 50 & 88 & 25 \\
\hline \multicolumn{9}{|l|}{ Public indoor } \\
\hline Public transport vehicle ${ }^{3}$ & 3 & 0 & 33 & 100 & 100 & 33 & 100 & 0 \\
\hline Mall & 8 & 50 & 75 & 63 & 88 & 88 & 100 & 13 \\
\hline Hotel & 9 & 11 & 67 & 89 & 100 & 89 & 56 & 11 \\
\hline Café or coffee shop & 11 & 9 & 82 & 91 & 100 & 82 & 73 & 9 \\
\hline Restaurant & 17 & 18 & 53 & 94 & 94 & 65 & 71 & 6 \\
\hline Child play station & 3 & 0 & 100 & 100 & 100 & 100 & 100 & 0 \\
\hline \multicolumn{9}{|l|}{ Public outdoor } \\
\hline Bus station ${ }^{4}$ & 4 & 25 & 25 & 25 & 50 & 0 & 100 & 0 \\
\hline Traditional market & 3 & 0 & 0 & 0 & 33 & 0 & 100 & 0 \\
\hline Recreational facility ${ }^{5}$ & 4 & 0 & 0 & 25 & 75 & 25 & 100 & 0 \\
\hline Sport facility ${ }^{6}$ & 4 & 25 & 75 & 75 & 100 & 75 & 100 & 0 \\
\hline Public park & 4 & 0 & 50 & 100 & 100 & 50 & 100 & 0 \\
\hline
\end{tabular}

$\mathrm{N}$, sample (purposive); No smoking, no smoking activity; No smoke, no cigarette smoke; Compliance with all 6, compliance with all 6 criteria (signage, no smoking, no selling, no advertisement, no smoke, and no ashtrays).

${ }^{1}$ Hospitals and educational facilities include government and private facilities.

${ }^{2}$ Places of worship include mosques, churches, and temples.

${ }^{3}$ Public transport vehicles include buses and taxis.

${ }^{4}$ Bus stations include bus and taxi terminals.

${ }^{5}$ Recreational facilities include beaches and swimming pools.

${ }^{6}$ Sport facilities include sport fields and football stadiums.

\section{Ethics Statement}

Ethical clearance was obtained from the Hasanuddin University Faculty of Public Health (No. 5493/UN4.14.8/TP.02.02/2).

\section{RESULTS}

Table 1 shows that among all facilities, the rate of compliance with all 6 criteria was $17 \%$ overall, with $50 \%$ compliance at health facilities, $29 \%$ at educational facilities, $15 \%$ at government offices, $8 \%$ at indoor public facilities, $3 \%$ at places of worship, and $0 \%$ at outdoor public facilities. The low rates were mainly due to the lack of signage and the presence of active smoking. More specifically, $80 \%$ of health facilities and $62 \%$ of government offices had no-smoking signage, but only $7 \%$ of places of worship and $11 \%$ of outdoor public facilities had such signage. Only $23 \%$ of government offices and $32 \%$ 


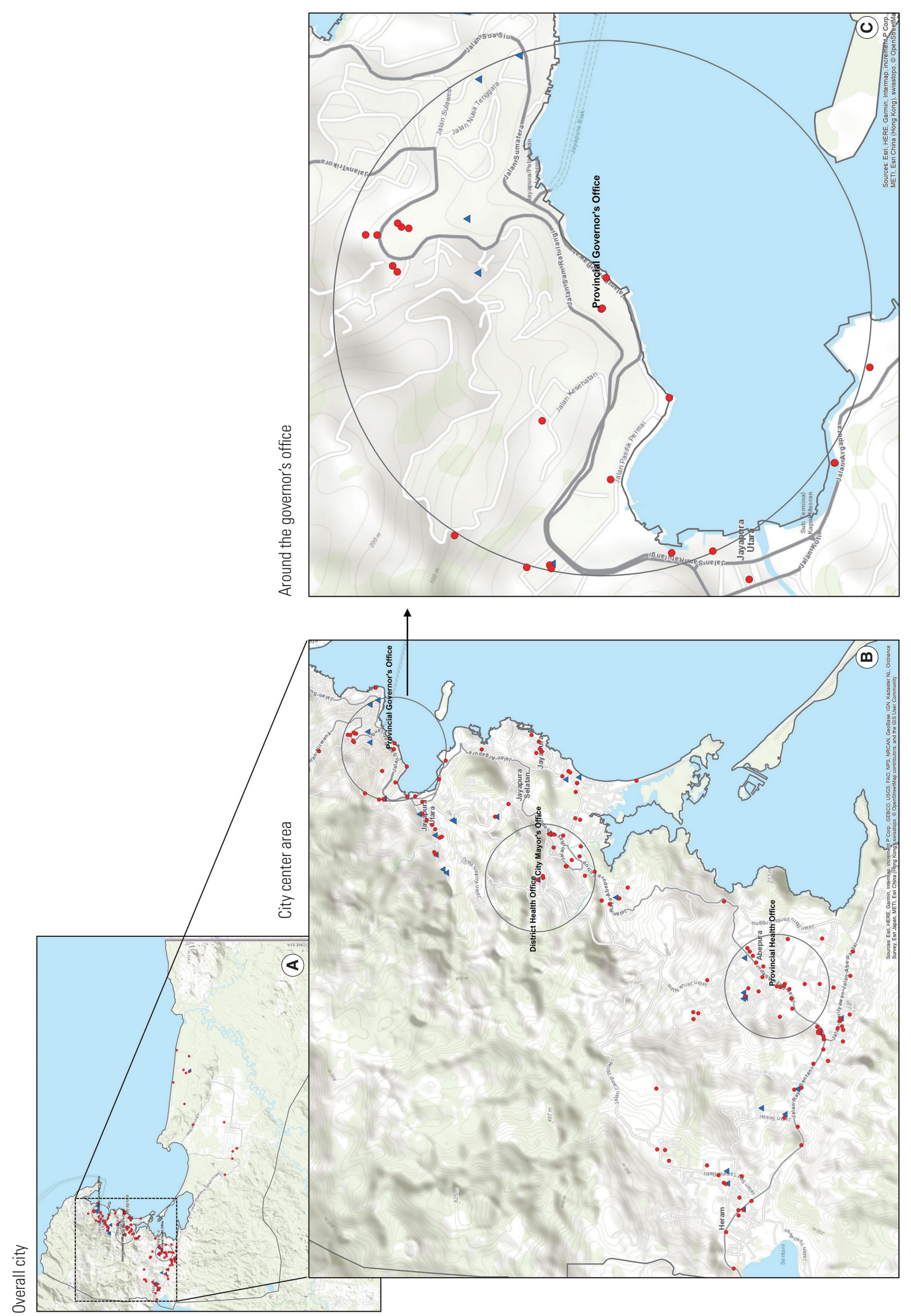

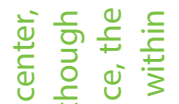

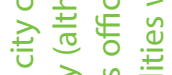

을 출 วิ \%

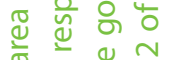
ㅎำ @ำ

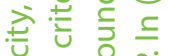

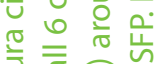

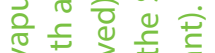

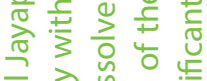

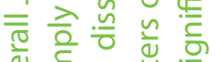
एँ

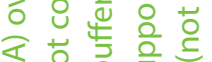
은

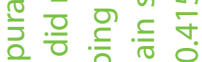
등 응 है

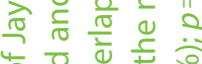

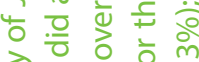

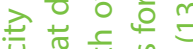

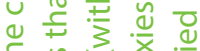

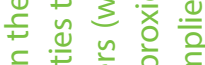

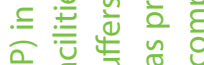

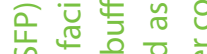
을 원 응 웅 $\frac{⿱ 亠 䒑}{!}$ 过 은 근 는 한

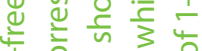
ब है 능 는 ये 중 $\mp \stackrel{0}{5} \frac{5}{\pi}$

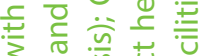
तथ 을 흗 늠 언

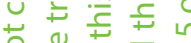

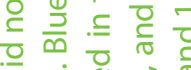

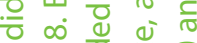
든 근 岂

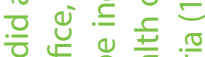
送造 造 돈 는 은

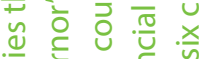

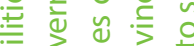

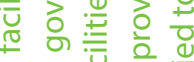

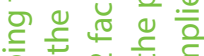

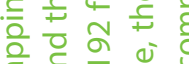
$\sum^{\frac{\pi}{\pi}} \overline{\frac{1}{5}}$

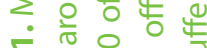
인

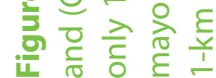


of outdoor public facilities lacked smoking activity. By facility type, among health facilities, the rate of compliance with all 6 criteria was lower at hospitals (33\%) than at government clinics (75\%); among educational facilities, the compliance rate was lowest at kindergartens (17\%) and highest at junior high schools (38\%); among indoor public facilities, the rate was lowest in public transport vehicles (0\%) and highest at malls (13\%); among outdoor public facilities, the rates were equally low at all facilities (bus stations, traditional markets, recreation and sport facilities, and parks), at $0 \%$.

Figure 1 shows the mapping of the facilities designed to explore spatial patterns in compliance: (A) shows the city of Jayapura as a whole, (B) shows the area around the city center, and (C) shows the area around the governor's office. Blue triangles and red dots correspond to facilities that did and did not comply with all 6 criteria, respectively (although only 190 of 192 facilities could be included in this analysis). Gray circles show 1-km buffers (with overlapping buffers dissolved) around the governor's office, the mayor's office, the provincial health office, and the district health office, which served as proxies for the main supporters of the SFP. Slightly higher rates of compliance with the 6 criteria were found among facilities inside the buffer (17\%) than among those outside the buffer (13\%), but the difference was not statistically significant $(p=0.415)$.

The content analysis demonstrated 4 main challenges in SFP implementation. First, the budget for enforcing the SFP was limited due to competition for funding with other government programs. Second, the effort lacked support from and collaboration with local non-governmental organizations and universities. Third, the effort lacked public awareness of the SFP at the facilities themselves. Fourth, there were no examples set by local government or community leaders, and such examples are important in settings where tribal culture is still applicable.

\section{DISCUSSION}

In Indonesia, the lowest rate of adoption of SFPs has been found in the easternmost regions, including Maluku, Nusa Tenggara, and Papua [6]. In addition, our results showed that the overall compliance with the SFP in Jayapura was also among the lowest rates that have been reported throughout Indonesia. Compliance was extremely low even at educational facilities (29\%) and government offices (15\%), partially due to challenges including a lack of examples from local leaders in following the law, limited enforcement, and a lack of support from and collaboration with local non-governmental organizations and universities. Another study has also demonstrated hesitation to socially enforce an SFP, particularly in the context of asking men of status and/or community leaders to stop smoking [12].

Other than this study, there is limited evidence regarding compliance with SFPs in low-income and middle-income countries. A study in Punjab, a fertile agricultural province in India with very strong tobacco control, showed very high overall compliance with an SFP (84\%); the lowest compliance was found at transit stations (79\%), while the highest was found at health facilities (90\%). Moreover, while another study showed that ashtrays were significant determinants of SFP success in Greece [13], this was not the case in Jayapura, where some locations had no ashtrays but still exhibited high rates of smoking. In government offices, for instance, $100 \%$ of facilities lacked ashtrays, but $77 \%$ had active smoking.

With regard to policy, the evidence in the present study should alert the central Indonesian government to act in order to improve the implementation of the SFP policy at the local level through better monitoring and public awareness, as well as additional funding for enforcement, among other policy options. With regard to future research, further studies should consider conducting random sampling of all SFP facilities to provide a more robust evaluation. Our study was limited to smoke-free areas; further studies should provide evidence on the progress (or lack thereof) of other tobacco control measures, such as outdoor advertisements.

\section{CONFLICT OF INTEREST}

The authors have no conflicts of interest associated with the material presented in this paper.

\section{ACKNOWLEDGEMENTS}

Support for this research was provided by the Center for Islamic Economics and Business, the University of Indonesia, with funding awarded by Bloomberg Philanthropies to Johns Hopkins University. Its content is solely the responsibility of the authors and do not necessarily represent the official views of Bloomberg Philanthropies or Johns Hopkins University. 


\section{AUTHOR CONTRIBUTIONS}

Conceptualization: WW, AA, DK. Data curation: WW, SKH, SNM. Formal analysis: WW, SKH, DK. Funding acquisition: WW, AA. Methodology: WW, AA, SK. Project administration: WW. Visualization: DK. Writing - original draft: DK, WW. Writing - review \& editing: DK, WW, SKH, SNM, AA.

\section{ORCID}

Wahyuti Wahyuti https://orcid.org/0000-0002-3816-8218

Suci K. Hasairin https://orcid.org/0000-0002-3975-1691

Sherly N. Mamoribo https://orcid.org/0000-0002-1921-9112

Abdillah Ahsan https://orcid.org/0000-0002-3543-7574

Dian Kusuma https://orcid.org/0000-0002-1909-9341

\section{REFERENCES}

1. World Health Organization. Factsheet 2018 Indonesia [cited 2018 Dec 12]. Available from: https://apps.who.int/iris/bitstream/handle/10665/272673/wntd_2018_indonesia_fs. pdf? sequence $=1$.

2. Ministry of Health Republic of Indonesia. Report of Riskesdas 2018 [cited 2018 Dec 12]. Available from: http://labmandat. litbang.depkes.go.id/images/download/laporan/RKD/2018/ Laporan_Nasional_RKD2018_FINAL.pdf(Indonesian).

3. World Health Organization, Regional Office for South East Asia. Global Adult Tobacco Survey: Indonesia report 2011; 2012 [cited 2019 Nov 14]. Available from: http://terbitan.litbang.depkes.go.id/penerbitan/index.php/lpb/catalog/ book/32.

4. President of Indonesia and Parliament. Health Act 36/2009 [cited 2019 Nov 14]. Available from: http://p2ptm.kemkes. go.id/uploads/2016/10/Undang-Undang-Republik-Indonesia-Nomor-36-Tahun-2009-Tentang-Kesehatan.pdf (Indonesian).
5. President of Republic of Indonesia. Presidential Decree number 109/2012 on safety of addictive substance in the form of tobacco product; 2012 [cited 2019 Nov 14]. Available from: https://sipuu.setkab.go.id/PUUdoc/173643/PP1092012.pdf (Indonesian).

6. Wahidin M, Hidayat MS, Arasy RA, Amir V, Kusuma D. Geographic distribution, socioeconomic disparity, and policy determinant of smoke-free policy adoption in Indonesia. Int J Tuberc Lung 2019 (in press).

7. Luntungan NN, Byron MJ, Hovell MF, Rosen LJ, Anggraeni A, Rees VW. Children's exposure to secondhand smoke during Ramadan in Jakarta, Indonesia. Int J Environ Res Public Health 2016;13(10):952.

8. Asyary A, Veruswati M. Compliance study of hotel and nightclub smoke-free zones in Bogor City, Indonesia. Tob Prev Cessat 2018;4:25.

9. Abubar M. Local legislator in Jayapura city criticized the implementation of SFP regulation. Antara News; 2017 Oct 13 [cited 2019 Apr 4]. Available from: https://papua.antaranews. com/berita/463157/legislator-dprd-kota-jayapura-kritisi-penerapan-perda-ktr (Indonesian).

10. Goel S, Sharma D, Gupta R, Mahajan V. Compliance with smokefree legislation and smoking behaviour: observational field study from Punjab, India. Tob Control 2018;27(4):407-413.

11. Statistics Bureau. Jayapura city in figures 2018 [cited 2019 Nov 14]. Available from: https://jayapurakota.bps.go.id/public ation/2018/08/16/774b52d53e3f175cc22a120a/kota-jayapura-dalam-angka-2018.html.

12. Kaufman MR, Merritt AP, Rimbatmaja R, Cohen JE. 'Excuse me, sir. Please don't smoke here'. A qualitative study of social enforcement of smoke-free policies in Indonesia. Health Policy Plan 2015;30(8):995-1002.

13. Vardavas Cl, Agaku I, Patelarou E, Anagnostopoulos N, Nakou C, Dramba V, et al. Ashtrays and signage as determinants of a smoke-free legislation's success. PLoS One 2013;8(9):e72945. 